\title{
KANDUNGAN SERAT, LEMAK, SIFAT FISIK, DAN TINGKAT PENERIMAAN ES KRIM DENGAN PENAMBAHAN BERBAGAI JENIS BEKATUL BERAS DAN KETAN
}

\author{
Riza Puspitarini, Arintina Rahayuni ${ }^{*}$ \\ Program Studi Ilmu Gizi Fakultas Kedokteran Universitas Diponegoro \\ Jl.Dr.Sutomo No.14, Semarang, Telp (024) 8453708, Email : gizifk@undip.ac.id
}

\begin{abstract}
Background: Fiber intake provides many health benefits including reduced risk for coronary heart disease, stroke, hypertension, diabetes, obesity and certain gastrointestinal disease. One of the foods that have high fiber content is rice bran. The addition of rice bran in ice cream to enrich the fiber content of ice cream, so that the ice cream is produced has more complete nutritional value. White rice, red rice, white glutinous rice, and black glutinous rice are well known by Indonesian people. Therefore, it is necessary to study about fiber and fat content of ice cream with the addition of white, red, white glutinous, and black glutinous rice bran.

Objective: Analyze the difference of fiber content, fat content, physical properties (overrun and melting rate), and level of acceptance by the addition different types of rice and glutinous rice bran in ice cream.

Methods: Experimental study completely randomized design with single factor. Rice bran varieties used were white, red, white glutinous, and black glutinous rice bran with addition of $10 \%$ rice bran. The analyzes are crude fiber content, fat content, physical properties, and level of acceptance of ice cream with the addition of rice and glutinous rice bran varieties. Data described the physical properties of ice cream by calculating the average overrun and melting rate. Statistical analysis of the fiber content using one way ANOVA, while the fat content using Kruskalwallis. The level of acceptance analyzed by Friedman test followed Wilcoxon test.

Results: The addition of different types of rice and glutinous rice bran statistically no effect on fiber and fat content of ice cream. The highest overrun is in the ice cream without the addition of rice bran. The lastest melting rate is in the of ice cream with the addition white rice and white glutinous rice bran. The addition of different types of rice and glutinous rice bran decrease level of acceptance includes the color, flavor, texture, and flavor of ice cream.

Conclusions: The highest fiber content is in the ice cream with the addition of black glutinous rice bran. The lowest fat content is in the ice cream with the addition of white rice bran. Recommended ice cream is ice cream with the addition of white glutinous rice bran.
\end{abstract}

Key Words: fat; fiber; ice cream; rice bran

\begin{abstract}
ABSTRAK
Latar Belakang: Asupan serat dapat memberikan manfaat bagi kesehatan diantaranya dapat menurunkan risiko terjadinya penyakit jantung koroner, stroke, hipertensi, diabetes, obesitas, dan gangguan pencernaan. Salah satu bahan makanan yang mempunyai kandungan serat tinggi adalah bekatul. Penambahan bekatul pada es krim dapat memperkaya kandungan serat es krim sehingga menghasilkan produk es krim yang memiliki nilai gizi lebih lengkap. Beras putih, beras merah, ketan putih, dan ketan hitam merupakan berbagai varietas beras yang sudah sangat dikenal oleh masyarakat Indonesia. Oleh karena itu, perlu dilakukan penelitian mengenai analisis kandungan serat dan lemak es krim dengan penambahan bekatul beras putih, beras merah, ketan putih, dan ketan hitam.

Tujuan: Menganalisis perbedaan kadar serat, lemak, sifat fisik(overrun dan melting rate), dan tingkat penerimaan es krim dengan penambahan berbagai jenis bekatul beras dan ketan.

Metode: Penelitian eksperimental dengan rancangan acak lengkap satu faktor. Jenis bekatul yang digunakan adalah bekatul beras putih, beras merah, ketan putih, dan ketan hitam dengan konsentrasi penambahan bekatul 10\%. Analisis yang dilakukan adalah kadar serat kasar, kadar lemak, sifat fisik, dan tingkat penerimaan es krim dengan penambahan bekatul berbagai varietas beras dan ketan. Data sifat fisik es krim dideskripsikan dengan menghitung rerata overrun dan melting rate. Kadar serat dianalisis menggunakan uji One Way ANOVA, sedangkan kadar lemak menggunakan uji Kruskal-wallis. Tingkat penerimaan dilakukan uji hedonik kemudian dianalisis dengan uji Friedman dan dilanjutkan uji Wilcoxon dengan derajat kepercayaan 95\%.

Hasil: Penambahan berbagai jenis bekatul beras dan ketan tidak berpengaruh secara statistik terhadap kadar serat dan lemak es krim. Overrun tertinggi adalah pada es krim kontrol. Es krim yang paling resiten terhadap pelelehan adalah es krim dengan penambahan bekatul beras putih dan ketan putih. Penambahan berbagai jenis bekatul beras dan ketan berpengaruh terhadap penurunan tingkat penerimaan yang meliputi warna, rasa, tekstur, dan aroma es krim.
\end{abstract}

\footnotetext{
${ }^{*}$ Penulis Penanggungjawab
} 
Simpulan: Kadar serat tertinggi adalah pada es krim dengan penambahan bekatul ketan hitam. Kadar lemak paling rendah adalah pada es krim dengan penambahan bekatul beras putih. Es krim yang direkomendasikan adalah es krim dengan penambahan bekatul ketan putih.

Kata kunci: lemak; serat; es krim; bekatul

\section{PENDAHULUAN}

Asupan serat dapat memberikan manfaat bagi kesehatan diantaranya adalah dapat menurunkan risiko terjadinya penyakit jantung koroner, stroke, hipertensi, diabetes, obesitas, dan gangguan pencernaan. Selain itu, peningkatan konsumsi serat juga dapat menurunkan tekanan darah, mengendalikan kadar gula darah, berperan dalam penurunan berat badan, dan fungsi imunitas. ${ }^{1}$ Berdasarkan hasil Riskesdas 2007, stroke adalah penyebab kematian utama dengan presentase $15,4 \%$. Prevalensi nasional penyakit jantung adalah $7,2 \%$ dan Jawa Tengah termasuk provinsi yang memiliki prevalensi penyakit jantung di atas prevalensi nasional. Prevalensi nasional obesitas penduduk di atas usia 15 tahun adalah $10,3 \%$. Prevalensi berat badan lebih anak usia sekolah (6 - 14 tahun) di Indonesia adalah 9,5\% untuk laki-laki dan $10,9 \%$ untuk perempuan. ${ }^{2}$ Meningkatnya prevalensi penyakit degeneratif akibat pola makan yang rendah serat menunjukkan bahwa konsumsi serat makanan menjadi kebutuhan yang harus dipenuhi. Rata-rata konsumsi serat masyarakat Indonesia adalah 10,5 gram/ hari, sementara rata-rata konsumsi serat di Propinsi Jawa Tengah sebesar 12,7 gram/ hari. Angka ini menunjukkan bahwa konsumsi serat penduduk Indonesia masih di bawah anjuran gizi, yaitu $20-30 \mathrm{gram} /$ hari. $^{3}$

Salah satu bahan makanan yang memiliki kandungan serat tinggi adalah bekatul. Bekatul merupakan lapisan sebelah dalam butiran padi termasuk sebagian endosperm berpati. Bekatul mengandung total serat makanan sebesar $21-27 \%$ dan lemak $18-22 \%$ yang terdiri dari asam lemak tidak jenuh tunggal dan asam lemak tidak jenuh ganda, ${ }^{4}$ serta berbagai vitamin dan mineral. ${ }^{5}$ Berbagai variasi jenis bekatul memiliki komposisi zat gizi yang berbeda satu sama lain, termasuk kandungan serat dan lemaknya. Kandungan lemak bekatul beras merah adalah $13,72 \%$, lebih tinggi daripada bekatul beras putih $9,12 \%$. Sementara itu, kandungan serat kasar bekatul beras merah adalah $13,44 \%$, lebih rendah daripada bekatul beras putih $15,06 \%{ }^{6}$ Disamping mengandung serat yang bermanfaat bagi tubuh, bekatul memiliki kelemahan yaitu mudah mengalami kerusakan enzimatis oleh enzim lipase sehingga mudah menjadi tengik. Namun, pengolahan bekatul lebih lanjut dapat memperpanjang umur simpan bekatul.

Es krim merupakan hidangan beku yang memiliki kandungan gizi tinggi dan banyak digemari masyarakat. Sekarang ini, konsumen es krim tidak hanya terbatas pada golongan anak-anak tetapi sudah meluas di kalangan remaja, dewasa, dan orang tua. Konsumsi es krim per kapita di Indonesia meningkat dari 0,3 liter menjadi 0,5 liter pada tahun $2004 .^{7}$ Perkembangan industri es krim di Indonesia semakin meningkat, banyak produk baru es krim bermunculan. Tahun 2003-2007, tingkat pertumbuhan pasar es krim di Indonesia meningkat $20 \%$ setiap tahunnya. Namun, produk es krim yang banyak beredar di pasaran saat ini adalah es krim kaya lemak tetapi rendah serat. Menurut Tabel Komposisi Pangan Indonesia, dalam 100 gram es krim mengandung 12,5 gram lemak dan hampir tidak memiliki kandungan serat. ${ }^{8}$

Penambahan bekatul dapat memperkaya kandungan serat es krim sehingga menghasilkan produk es krim yang memiliki nilai gizi lebih lengkap. Dalam penelitian Hilmansyah, es krim dengan penambahan bekatul memiliki kadar lemak total lebih rendah dibanding kadar lemak total es krim kontrol. Selain itu, es krim dengan penambahan bekatul menunjukkan adanya aktivitas antioksidan. ${ }^{9}$

Beras putih, beras merah, ketan putih, dan ketan hitam merupakan berbagai varietas beras yang sudah sangat dikenal oleh masyarakat Indonesia. Oleh karena itu, perlu dilakukan penelitian mengenai analisis kandungan serat, lemak, sifat fisik (melting rate dan overrun), dan tingkat penerimaan es krim dengan penambahan bekatul beras putih, beras merah, ketan putih, dan ketan hitam.

\section{METODA}

Penelitian ini merupakan penelitian dalam bidang food production. Penelitian dilaksanakan di Laboratorium Ilmu Teknologi Pangan Universitas Muhammadiyah Semarang dan Laboratorium Ilmu Pangan Universitas Katholik Soegijapranata Semarang. 
Penelitian ini merupakan penelitian eksperimental dengan rancangan acak lengkap satu faktor, yaitu varietas bekatul beras dan ketan: (1) es krim tanpa penambahan bekatul (sebagai kontrol), (2) es krim dengan penambahan bekatul beras putih, (3) es krim dengan penambahan bekatul beras merah, (4) es krim dengan penambahan bekatul ketan putih, dan (5) es krim dengan penambahan bekatul ketan hitam. Konsentrasi penambahan bekatul adalah $10 \%$, ditentukan berdasarkan hasil penelitian pendahuluan. Pada penelitian pendahuluan es krim dibuat dengan penambahan bekatul 10\%, 20\%, dan $30 \%$. Berdasarkan hasil penelitian pendahuluan diketahui bahwa es krim dengan penambahan bekatul $10 \%$ adalah yang paling disukai panelis dengan rerata skor 3,51 dan termasuk kategori suka. Setiap pengujian dilakukan dua kali ulangan dan diuji secara duplo, sedangkan tingkat penerimaan es krim dengan penambahan berbagai jenis bekatul beras dan ketan dilakukan 1 kali.

Es krim dengan penambahan bekatul dibuat dari bahan baku susu skim $11 \%$, whippedcream $12 \%$, gula pasir $15 \%$, CMC $0,2 \%$, dan kuning telur $0,2 \%$, air, ${ }^{10}$ dan dengan atau tanpa penambahan bekatul. Sebelum dicampurkan dengan bahan baku lain, bekatul disangrai terlebih dahulu. Bekatul yang digunakan adalah bekatul beras putih, beras merah, ketan putih, dan ketan hitam dari Desa Batursari, Kabupaten Demak, Provinsi Jawa Tengah. Es krim dibuat melalui proses pencampuran, pasteurisasi, homogenisasi menggunakan ice cream maker, dan pembekuan.

Pada penelitian utama, data yang dikumpulkan adalah kadar serat kasar, kadar lemak, sifat fisik (melting rate dan overrun), dan tingkat penerimaan es krim dengan penambahan berbagai jenis bekatul beras dan ketan. Kadar serat kasar diukur dengan metode gravimetri dan kadar lemak diukur dengan metode soxhlet. Melting rate diketahui dengan menghitung waktu leleh (time to melt) es krim dan nilai overrun diperoleh dari perhitungan perbedaan volume adonan es krim dan volume es krim dengan menggunakan analog air. ${ }^{11}$ Tingkat penerimaan warna, aroma, tekstur, dan rasa dilakukan menggunakan 5 skala hedonik (1=Sangat Tidak Suka, 2=Tidak Suka, 3=Netral, 4=Suka, 5=Sangat Suka), panelis agak terlatih yang terdiri dari 20 orang mahasiswa Program Studi Ilmu Gizi Universitas Diponegoro. Pengaruh penambahan berbagai jenis bekatul beras dan ketan terhadap kadar serat diuji dengan one way Anova dan kadar lemak diuji dengan Kruskal-wallis derajat kepercayaan 95\%. Data melting rate dan overrun dihitung rerata untuk mendeskripsikan sifat fisik es krim. Data tingkat penerimaan dianalisis dengan uji Friedman dilanjutkan uji Wilcoxon untuk mengetahui beda nyata antar perlakuan dengan derajat kepercayaan $95 \%$.

\section{HASIL}

\section{Kandungan Zat Gizi Bekatul}

Hasil analisis kandungan zat gizi bekatul dapat dilihat pada Tabel 1. Bekatul beras putih memiliki kandungan protein tertinggi, yaitu 20,48\%. Bekatul ketan putih memiliki kandungan lemak dan abu tertinggi, yaitu $16,68 \%$ dan $11,80 \%$. Kandungan serat kasar tertinggi adalah bekatul beras merah, yaitu 10,08\%. Bekatul ketan hitam memiliki kadar karbohidrat dan air tertinggi dibandingkan dengan bekatul jenis lain, yaitu $57,69 \%$ dan $9,54 \%$.

Tabel 1. Rerata Kandungan Zat Gizi Bekatul

\begin{tabular}{ccccccc}
\hline Jenis & \multicolumn{5}{c}{ Rerata Kandungan gizi } \\
\cline { 2 - 7 } & Protein & Lemak & Karbohidra & Abu & Serat & Air \\
Kasar & \\
\hline Beras & $20.48 \pm 1.4$ & $15.89 \pm 1.6$ & $44.36 \pm 0.43$ & $9.76 \pm 0.18$ & $9.25 \pm 0.21$ & $8.45 \pm 0.49$ \\
Putih & 5 & 5 & $49.44 \pm 0.86$ & $8.62 \pm 0.11$ & $10.08 \pm 1.7$ & $8.70 \pm 0.14$ \\
Beras & $18.15 \pm 1.9$ & $15.15 \pm 0.0$ & $50.13 \pm 0.81$ & $11.80 \pm 0.2$ & 0 & $7.09 \pm 0.15$ \\
Merah & 4 & 2 & $57.69 \pm 0.69$ & 8 & $6.25 \pm 0.33$ & $9.52 \pm 0.74$ \\
Ketan & $13.60 \pm 0.7$ & $16.68 \pm 0.1$ & & $8.16 \pm 0.23$ & $7.15 \pm 0.06$ & \\
putih & 8 & 3 & & & & \\
Ketan & $14.01 \pm 0.8$ & $9.89 \pm 0.01$ & & & & \\
hitam & 4 & & & & & \\
\hline
\end{tabular}

\section{Kadar Serat Es Krim Bekatul}

Kadar serat kasar es krim dengan penambahan berbagai jenis bekatul beras dan ketan memiliki rerata antara $1,65 \%-3,05 \%$. Kadar serat tertinggi adalah es krim bekatul ketan hitam, sedangkan kadar serat paling 
rendah adalah es krim kontrol. Hasil analisis kadar serat menggunakan uji one way Anova CI 95\% menunjukkan bahwa penambahan berbagai jenis bekatul beras dan ketan tidak berpengaruh nyata terhadap peningkatan kadar serat es krim. Hasil analisis kadar serat kasar es krim dengan penambahan berbagai jenis bekatul beras dan ketan dapat dilihat pada Tabel 2 .

Tabel 2. Rerata Kadar Serat Es Krim dengan Penambahan Berbagai Jenis Bekatul Beras dan Ketan

\begin{tabular}{cc}
\hline Perlakuan Es Krim & Rerata \\
\hline Kontrol & $1,65 \pm 0,70$ \\
Bekatul Beras Putih & $2,12 \pm 0,02$ \\
Bekatul Beras Merah & $2,80 \pm 0,41$ \\
Bekatul Ketan Putih & $1,95 \pm 0,40$ \\
Bekatul Ketan Hitam & $3,05 \pm 0,38$ \\
\hline & $\mathrm{p}=0,097$ \\
\hline
\end{tabular}

\section{Kadar Lemak Es Krim Bekatul}

Kadar lemak es krim dengan penambahan berbagai jenis bekatul beras dan ketan memiliki rerata antara $0,70 \%-3,17 \%$. Kadar lemak tertinggi adalah es krim kontrol, sedangkan kadar lemak paling rendah adalah es krim bekatul beras putih. Hasil analisis kadar lemak menggunakan uji Kruskal-Wallis menunjukkan bahwa penambahan berbagai jenis bekatul beras dan ketan tidak berpengaruh nyata terhadap penurunan kadar lemak es krim. Hasil analisis kadar lemak es krim dengan penambahan berbagai jenis bekatul beras dan ketan dapat dilihat pada Tabel 3.

Tabel 3. Rerata Kadar Lemak Es Krim dengan Penambahan Berbagai Jenis Bekatul Beras dan Ketan

\begin{tabular}{cl}
\hline Perlakuan Es Krim & Rerata \\
\hline Kontrol & $3,17 \pm 1,57$ \\
Bekatul Beras Putih & $0,70 \pm 0,02$ \\
Bekatul Beras Merah & $1,18 \pm 0,54$ \\
Bekatul Ketan Putih & $1,83 \pm 0,00$ \\
Bekatul Ketan Hitam & $1,13 \pm 0,28$ \\
\hline & $\mathrm{p}=0,081$ \\
\hline
\end{tabular}

\section{Sifat Fisik Es Krim Bekatul}

Rerata nilai overrun es krim dengan penambahan berbagai jenis bekatul beras dan ketan berkisar antara 40,80\% - 78,65\%. Rerata nilai overrun tertinggi adalah es krim kontrol, sedangkan rerata nilai overrun paling rendah pada es krim bekatul ketan hitam.

Rerata melting rate es krim dengan penambahan berbagai jenis bekatul beras dan ketan berkisar antara $0,23-0,52 \mathrm{ml} /$ menit. Es krim bekatul beras merah memiliki melting rate tertinggi. Nilai melting rate paling rendah adalah es krim bekatul beras putih dan bekatul ketan putih. Hasil rerata nilai overrun dan melting rate secara singkat dapat dilihat pada Tabel 4.

Tabel 4. Rerata Sifat Fisik (Overrun dan Melting Rate) Es Krim dengan Penambahan Berbagai Jenis Bekatul Beras dan Ketan

\begin{tabular}{ccc}
\hline Perlakuan & Overrun $\mathbf{( \% )}$ & Melting Rate $(\mathbf{m l} / \mathbf{m e n i t})$ \\
\hline Kontrol & $78,65 \pm 5,16$ & $0,45 \pm 0,44$ \\
Bekatul Beras Putih & $75,70 \pm 6,06$ & $0,23 \pm 0,16$ \\
Bekatul Beras Merah & $66,20 \pm 5,30$ & $0,52 \pm 0.00$ \\
Bekatul Ketan Putih & $65,00 \pm 7,07$ & $0,23 \pm 0,24$ \\
Bekatul Ketan Hitam & $40,80 \pm 1,13$ & $0,37 \pm 0,17$ \\
\hline
\end{tabular}




\section{Tingkat Penerimaan Es Krim Bekatul}

Data tingkat penerimaan es krim dengan penambahan berbagai jenis bekatul beras dan ketan didapatkan dengan melaksanakan uji hedonik meliputi penilaian warna, rasa, tekstur, dan aroma. Hasil rerata tingkat penerimaan dapat dilihat dalam Tabel 5.

Tabel 5. Rerata Tingkat Kesukaan Panelis terhadap Es Krim dengan Penambahan Berbagai Jenis Bekatul Beras dan Ketan

\begin{tabular}{|c|c|c|c|c|c|c|c|c|}
\hline \multirow{2}{*}{$\begin{array}{c}\text { Jenis Es } \\
\text { Krim }\end{array}$} & \multicolumn{2}{|c|}{ Warna } & \multicolumn{2}{|c|}{ Aroma } & \multicolumn{2}{|c|}{ Tekstur } & \multicolumn{2}{|c|}{ Rasa } \\
\hline & Rerata & Keterangan & Rerata & Ket & Rerata & Ket & Rerata & Ket \\
\hline Kontrol & $4.60 \pm 0.5$ & Sangat & $4.15 \pm 0.67$ & Suka & $4.45 \pm 0.51$ & Suka & $4.75 \pm 0.44$ & Sangat \\
\hline $\mathrm{BP}$ & $0^{\mathrm{a}}$ & Suka & 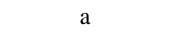 & Netra & 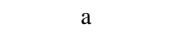 & Netra & & Suka \\
\hline BM & $3.25 \pm 0.7$ & Netral & $3.10 \pm 0.64$ & 1 & $3.30 \pm 0.97$ & 1 & $1.90 \pm 0.55$ & Tidak Suka \\
\hline $\mathrm{KP}$ & $1^{\mathrm{cd}}$ & Suka & b & Netra & $\mathrm{c}$ & Netra & c & Tidak Suka \\
\hline KH & $3.90 \pm 0.8$ & Suka & $3.20 \pm 0.61$ & 1 & $3.30 \pm 0.73$ & 1 & $2.30 \pm 0.73$ & Netral \\
\hline & $5^{\mathrm{bc}}$ & Netral & & Netra & & Suka & & Tidak suka \\
\hline & $\begin{array}{c}3.50 \pm 0.6 \\
8^{c}\end{array}$ & & $3.45 \pm 0.60$ & $\begin{array}{c}1 \\
\text { Netra }\end{array}$ & $3.65 \underset{\mathrm{bc}}{ \pm 0.74}$ & Netra & $3.10 \pm \frac{\mathrm{b}}{\mathrm{b}} 1.07$ & \\
\hline & $3.40 \pm 1.0$ & & $3.25 \pm 0.71$ & 1 & $3.15 \pm 0.87$ & & $2.00 \pm 0.72$ & \\
\hline & $\mathrm{p}=0,000$ & & $\mathrm{p}=0,000$ & & $\mathrm{p}=0,000$ & & $\mathrm{p}=0,000$ & \\
\hline
\end{tabular}

Keterangan: Angka yang diikuti dengan huruf superscript berbeda (a, b, c, d) menunjukkan beda nyata (BP=Bekatul Beras Putih, BM=Bekatul Beras Merah, KP=Bekatul Ketan Putih, KH=Bekatul Ketan Hitam)

Tingkat penerimaan panelis terhadap parameter warna es krim dengan penambahan berbagai jenis bekatul beras dan ketan memiliki rerata antara 3,25 - 4,60. Rerata paling rendah pada es krim bekatul beras putih dan rerata paling tinggi adalah es krim kontrol. Berdasarkan uji lanjut Wilcoxon, es krim kontrol memiliki perbedaan bermakna dengan semua perlakuan es krim dengan penambahan bekatul baik bekatul beras putih, beras merah, ketan putih, maupun ketan hitam. Selain itu, es krim bekatul beras putih juga berbeda bermakna dengan es krim bekatul beras merah.

Hasil analisis tingkat penerimaan aroma es krim dengan penambahan berbagai jenis bekatul beras dan ketan menunjukkan bahwa es krim kontrol merupakan es krim dengan tingkat penerimaan aroma paling tinggi dengan rerata 4,15 dan tingkat penerimaan aroma es krim terendah adalah es krim bekatul beras putih dengan rerata 3,10. Berdasarkan uji lanjut Wilcoxon, es krim kontrol berbeda bermaknaP dengan semua es krim yang ditambah bekatul baik bekatul beras putih, beras merah, ketan putih, maupun ketan hitam.

Tingkat penerimaan panelis terhadap tekstur es krim dengan penambahan berbagai jenis bekatul beras dan ketan memiliki rerata antara 3,15-4,45. Rerata paling rendah adalah es krim bekatul ketan hitam dan rerata paling tinggi adalah es krim kontrol. Berdasarkan uji lanjut Wilcoxon, es krim kontrol berbeda bermakna dengan semua es krim yang ditambah bekatul baik bekatul beras putih, beras merah, ketan putih, maupun ketan hitam. Selain itu, es krim bekatul ketan putih berbeda bermakna dengan es krim bekatul ketan hitam.

Hasil analisis tingkat penerimaan panelis terhadap rasa menunjukkan bahwa tingkat penerimaan terendah adalah es krim bekatul beras putih dengan nilai rerata 1,90 dan tingkat penerimaan tertinggi adalah es krim kontrol dengan rerata 4,75. Berdasarkan uji lanjut Wilcoxon, es krim kontrol berbeda bermakna dengan semua es krim yang ditambah bekatul baik bekatul beras putih, beras merah, ketan putih, maupun ketan hitam. Selain itu, perlakuan es krim bekatul ketan putih berbeda bermakna dengan es krim yang ditambah bekatul beras putih, beras merah, dan ketan hitam.

\section{Kadar Serat Es Krim Bekatul}

Kadar serat es krim dengan penambahan bekatul mengalami peningkatan bila dibandingkan dengan kadar serat es krim kontrol. Nilai rerata paling rendah adalah es krim kontrol, sedangkan kadar serat tertinggi adalah es krim bekatul ketan hitam. Namun, berdasarkan analisis statistik penambahan 
berbagai jenis bekatul beras dan ketan tidak berpengaruh nyata terhadap kadar serat es krim. Hal ini akibat bekatul yang ditambahkan pada es krim relatif rendah, yaitu $10 \%$. Selain itu, kadar serat berbagai jenis bekatul beras dan ketan tidak memiliki selisih terlalu jauh, yaitu antara $6,25-10,08 \%$.

Kandungan serat pada es krim kontrol ini karena adanya penambahan CMC (Carboxy Methyl Cellulose) sebagai bahan penstabil dalam pembuatan es krim. CMC merupakan turunan selulosa yang dimodifikasi secara kimia. CMC dibuat dari selulosa alami yang direaksikan dengan larutan $\mathrm{NaOH}$, kemudian selulosa alkali tersebut direaksikan dengan sodium mono kloro asetat. ${ }^{12}$

Selulosa merupakan salah satu polimer tidak bercabang dari unit $\beta$-1,4-d-glukopiranosa yang menjadi komponen struktural utama tanaman hijau. Kurangnya asupan serat (selulosa dan pentosa) dapat menyebabkan terjadinya konstipasi pada anak. Selulosa dapat mengikat air dalam usus tetapi tidak dapat dicerna oleh enzim pencernaan di usus halus atau difermentasi dalam usus besar oleh bakteri, sehingga bertambahnya asupan selulosa dapat meningkatkan volume usus dan feses. ${ }^{4}$

\section{Kadar Lemak Es Krim Bekatul}

Es krim dengan penambahan berbagai jenis bekatul beras dan ketan memiliki kadar lemak lebih rendah dibanding es krim kontrol. Penambahan berbagai jenis bekatul sebesar $10 \%$ menyumbangkan lemak $0,98-1,58$ gram, sedangkan lemak yang ditambahkan pada es krim adalah 4,2 gram untuk 100 gram adonan es krim. Sumbangan lemak yang rendah dari bekatul ini yang menyebabkan kadar lemak es krim yang ditambah bekatul menurun. Namun, berdasarkan analisis statistik penambahan berbagai jenis bekatul beras dan ketan tidak berpengaruh nyata terhadap kadar lemak es krim.

Penelitian Hilmansyah menunjukkan penambahan bekatul menyebabkan kadar lemak total es krim lebih rendah dibandingkan kadar lemak total es krim kontrol. Penambahan bekatul juga menyebabkan kadar trigliserida es krim menurun, tetapi kadar asam lemak bebas es krim meningkat. Hal ini karena asam lemak bebas dalam bekatul lebih tinggi daripada asam lemak bebas es krim. ${ }^{9}$ Penelitian Aryusuk menunjukkan minyak bekatul mengandung 3$20 \%$ asam lemak bebas. ${ }^{13}$ Kandungan asam lemak bebas yang tinggi mengakibatkan rentan terjadinya oksidasi dan mengalami ketengikan. Namun, hal ini dapat dikendalikan dengan melakukan pengamanan bekatul dengan benar. Pengamanan dapat dilakukan dengan pemanasan atau pengeringan, penyimpanan vacum, dan penambahan antioksidan. ${ }^{14}$

\section{Sifat Fisik Es Krim Bekatul}

Overrun merupakan pengembangan volume es krim terhadap volume adonan mulamula karena adanya udara yang terperangkap dalam es krim. Penambahan volume es krim terjadi melalui proses pemutaran dan pembekuan pada ice cream machine. ${ }^{10}$

Overrun yang lebih rendah pada es krim dengan penambahan bekatul disebabkan tingginya tingkat kekentalan adonan. Penambahan bekatul mengakibatkan es krim memiliki bahan kering lebih banyak dengan kadar air tetap sehingga adonan es krim dengan penambahan bekatul lebih kental dibanding adonan es krim kontrol. Selain itu, ukuran partikel yang berbeda setiap jenis bekatul juga dapat mempengaruhi kekentalan adonan es krim. Ukuran partikel bekatul yang lebih besar menyebabkan bekatul memiliki kelarutan pada air yang lebih rendah, sehingga adonan es krim menjadi lebih kental. Semakin kental adonan menyebabkan tegangan permukaan menjadi lebih besar sehingga udara sulit menembus permukaan dan pengembangan es krim yang dihasilkan menjadi lebih rendah. ${ }^{10}$

Standar overrun yang baik untuk skala rumah tangga berkisar $35-50 \%$, sedangkan untuk skala industri $70-80 \% .^{15}$ Overrun es krim bekatul ketan hitam sesuai dengan standar overrun skala rumah tangga. Overrun es krim kontrol dan es krim bekatul beras putih sudah sesuai dengan standar overrun skala industri, sedangkan es krim bekatul beras merah dan bekatul ketan putih memiliki overrun yang mendekati standar overrun skala industri.

Overrun es krim dapat mempengaruhi nilai gizi es krim. Nilai overrun yang tinggi menunjukkan pengembangan es krim yang lebih besar sehingga nilai gizi bahan-bahan yang ditambahkan pada es krim menurun. Es krim dengan overrun rendah mengalami penurunan nilai gizi yang lebih sedikit.

Melting rate merupakan banyaknya es krim yang meleleh dalam waktu tertentu ketika berada pada suhu ruang. ${ }^{16}$ Es krim yang berkualitas baik resisten terhadap pelelehan, tidak cepat meleleh pada suhu ruang. Es krim bekatul beras putih dan bekatul ketan putih 
memiliki melting rate yang lebih lama dibanding es krim kontrol. Sedangkan, es krim bekatul beras merah memiliki melting rate lebih cepat daripada es krim kontrol. Melting rate dipengaruhi oleh ukuran kristal es, koefisien konsistensi adonan, jumlah udara yang terperangkap, dan jaringan globula lemak yang terbentuk selama pembekuan. ${ }^{11}$

\section{Tingkat Penerimaan Es Krim Bekatul}

\section{a) Warna}

Es krim yang baik memiliki warna menarik, seragam, dan sesuai rasa tertentu yang ditambahkan. Es krim kontrol dalam penelitian ini adalah jenis es krim vanila yang memiliki warna putih cream yang sesuai dengan karakteristik warna sejati dari lemak susu. ${ }^{17}$

Berbeda dengan warna es krim kontrol, warna es krim dengan penambahan berbagai jenis bekatul beras dan ketan bervariasi sesuai jenis bekatul yang ditambahkan. Es krim dengan penambahan bekatul beras putih dan ketan putih memiliki warna kecoklatan fisik lapisan kulit padi. Es krim bekatul beras merah berwarna coklat kemerahan seperti warna beras merah dan es krim bekatul ketan hitam memiliki warna ungu gelap sesuai warna ketan hitam.

Berbagai warna pada bekatul ini merupakan hasil dari senyawa fitokimia yang terakumulasi dalam pericarp dan aleuron. Senyawa ini mengandung pigmen antosianin yang berhubungan dengan warna seperti ungu, merah atau hitam. ${ }^{18}$

b) Aroma

Es krim termasuk kelompok makanan beku sehingga zat yang berada di dalam es krim menjadi tidak menguap dan mengakibatkan aroma dari es krim hanya sedikit yang dapat tercium. ${ }^{17}$ Es krim kontrol memiliki aroma alami lemak susu yang berasal dari bahan baku es krim. Es krim yang ditambahkan bekatul memiliki aroma langu dari bekatul. Hal ini mengakibatkan penurunan tingkat penerimaan aroma es krim dengan penambahan bekatul. Aroma langu ini sudah berkurang karena bekatul telah disangrai terlebih dahulu. Pemanasan bekatul dilakukan untuk menurunkan kadar air dan menghambat kerja enzim lipase yang dapat menghidrolisis lemak menjadi asam lemak bebas dan mengakibatkan bekatul tengik.

c) Tekstur
Tekstur merupakan bagian penting dari es krim dan sebagai indikator bagi kualitas es krim yang baik. Tekstur es krim dapat dinilai dengan sentuhan lidah secara langsung. Tekstur es krim yang baik adalah lembut di dalam mulut. ${ }^{17}$ Lemak susu akan memberikan tekstur lembut pada es krim dengan memperkecil pembentukan kristal es saat pembekuan. Kuning telur sebagai pengemulsi berperan membentuk sel udara yang kecil dan seragam sehingga memberikan tekstur yang lembut pada es krim. CMC sebagai penstabil berfungsi mengikat air dan membentuk kristal es yang kecil sehingga menghasilkan tekstur es krim yang lembut. ${ }^{10}$

Perlakuan es krim kontrol memiliki tekstur creamy dan lembut, berbeda dengan es krim dengan penambahan berbagai jenis bekatul beras dan ketan yang memiliki tekstur kasar akibat penambahan bekatul. Dalam penelitian ini, bekatul diayak dengan ukuran 100 mesh, tetapi ternyata masih terasa kasar. Pengayakan 100 mesh dilakukan dengan harapan bekatul mencapai tingkat kehalusan yang sama dengan tepung terigu sehingga dapat tercampur homogen dengan air. Namun, bekatul memiliki tingkat kelarutan dalam air yang lebih kecil dan partikel yang lebih besar sehingga menghasilkan kristal es yang lebih besar pada es krim. Hal ini mengakibatkan tekstur es krim dengan penambahan bekatul terasa kasar. Bekatul yang ditambahkan pada es krim dapat diperkecil hingga 300 mesh sehingga dapat menghasilkan tekstur es krim yang lebih lembut.

d) Rasa

Es krim berkualitas baik memiliki rasa manis. Es krim kontrol memiliki rasa lemak susu dan manis yang berbaur satu sama lain. ${ }^{17}$ Penambahan bekatul mempengaruhi campuran bahan pembuatan es krim. Presentase penambahan gula tetap sebesar $15 \%$ sementara ada penambahan $10 \%$ bekatul. Hal ini mengakibatkan rasa manis es krim berkurang. Penambahan gula dapat dilakukan untuk memperbaiki rasa es krim bekatul. Selain itu, semua perlakuan es krim dengan penambahan berbagai jenis bekatul beras dan ketan memiliki aftertaste pahit. Rasa pahit ini berasal dari saponin yang terkandung pada bekatul. 
Es krim bekatul ketan putih merupakan perlakuan es krim bekatul yang masih dapat diterima panelis dengan kategori netral. Hal ini dapat disebabkan es krim bekatul ketan putih memiliki kadar lemak lebih tinggi dibandingkan es krim dengan penambahan bekatul jenis lain. Pada cita rasa, lemak akan berkontribusi dengan rasa dan memberikan efek sinergis pada tambahan flavor yang digunakan pada es krim. ${ }^{10}$

Berasarkan hasil penelitian ini, es krim yang direkomendasikan adalah es krim bekatul ketan putih. Es krim bekatul ketan putih memiliki skor tingkat penerimaan meliputi warna, aroma, tekstur, dan rasa yang paling baik jika dibandingkan dengan es krim dengan penambahan bekatul jenis lain (bekatul beras putih, beras merah, dan ketan hitam). Selain itu, es krim bekatul ketan putih termasuk es krim yang paling resisten terhadap pelelehan dan memiliki overrun yang sudah mendekati nilai standar overrun skala industri. Es krim bekatul ketan putih juga memiliki kadar serat lebih tinggi dan kadar lemak lebih rendah jika dibandingkan dengan es krim kontrol.

\section{SIMPULAN}

1. Penambahan berbagai jenis bekatul beras dan ketan tidak berpengaruh secara statistik terhadap kadar serat es krim dan kadar serat paling tinggi adalah es krim bekatul ketan hitam.

2. Penambahan berbagai jenis bekatul beras dan ketan tidak berpengaruh secara statistik terhadap kadar lemak es krim dan kadar lemak paling rendah adalah es krim bekatul beras putih.

3. Overrun es krim bekatul beras putih sudah sesuai dengan standar overrun es krim untuk skala industri. Es krim yang paling tahan terhadap pelelehan adalah es krim bekatul beras putih dan ketan putih.

4. Penambahan berbagai jenis bekatul beras dan ketan berpengaruh terhadap penurunan tingkat penerimaan yang meliputi warna, rasa, tekstur, dan aroma es krim.

\section{SARAN}

1. Berdasarkan hasil penelitian, es krim yang direkomendasikan adalah es krim bekatul ketan putih.
2. Pemberian bubuk coklat dapat dilakukan untuk meningkatkan penerimaan warna dan aroma es krim dengan penambahan bekatul.

3. Penambahan gula dapat dilakukan untuk meningkatkan penerimaan rasa es krim dengan penambahan bekatul.

\section{DAFTAR PUSTAKA}

1. Anderson JW, Baird P, Davis Jr, Ferreri S, Knudtson M, Koraym A, et.al. Health Benefits of Dietary Fiber. International Life Sciences Institute. Nutrition Reviews Vol. 67(4):188-205; 2009.

2. Departemen Kesehatan Republik Indonesia. Laporan Hasil Riset Kesehatan Dasar (RISKESDAS) Indonesia tahun 2007. Jakarta: Badan Penelitian dan Pengembangan Kesehatan; 2008.

3. Abas B. Jahari, Iman Sumarno. Epidemiologi Konsumsi Serat di Indonesia. Majalah Gizi Indonesia; 2001; 25: 37-56.

4. Kahlon TS. Rice Bran: Production, Composition, Functionality and Food Application, Physiological Benefits. In: Cho S, Priscilla S, editors. Fiber Ingredients : Food Applications and Health Benefits. Boca Raton. CRC Press; 2009.p.305-322.

5. Frei $\mathrm{M}$, Becker $\mathrm{K}$. On Rice, Biodiversity and Nutrition. Germany: Institute of Animal Production in the Tropics and Subtropics, Dept. of Aquaculture Systems and Animal Nutrition, University of Hohenheim. D-70599 Stuttgart; 2005.

6. Newi Iriyani. Sereal dengan Substitusi Bekatul Tinggi Antioksidan. [Skripsi]. Fakultas Kedokteran. Semarang: Universitas Diponegoro. 2011.

7. Fitrahdini, Ujang Sumarwan, Rita Nurmalia. Analisis Persepsi Konsumen Terhadap Ekuita Merek Produk Es Krim. Jur. Ilm. Kel. dan Kons., Januari 2010, p : 74-81 Vol. 3, No. 1 ISSN : 1907 $-6037$.

8. Mien K. Mahmud, Hermana, Nils Aria Zulfianto, Rossi Rozana, Apriyantono, dkk. Tabel Komposisi Pangan Indonesia (TKPI). Jakarta: Elex Media Komputindo; 2008.

9. Hilmansyah. Fortifikasi Bekatul Padi dan Pengaruhnya terhadap Kandungan Gizi Es Krim. [Skripsi]. Fakultas Pendidikan Matematika dan Ilmu Pengetahuan Alam. Universitas Pendidikan Indonesia; 2011.

10. Potter NN, Hotchkiss JH. Food science 5th edition. New York: International Thomson Publishing; 1995.p.293-314.

11. Muse MR, Hartel RW. Ice Cream Structural Elements that Affect Melting Rate and Hardness. J. Dairy Sci. 87:1-10; 2004.

12. Glicksman, M. Food Hydrocoloids Volume 1. Florida: CRC Press, Inc; 2000.p.199. 
13. Aryusuk. Effects of Crude Rice Bran Oil Components on Alkalirefining Loss. J. Am. Oil Chem. Soc. 475; 2008.

14. Tien R. Muchtadi, Sugiyono, Fitriyono Ayustaningwarno. Ilmu Pengetahuan Bahan Pangan. Bogor: Alfabeta; 2010. Hal. 277-282.

15. Tri Eko Susilorini dan Manik Eirry Sawitri. Produk Olahan Susu. Jakarta: Penebar Swadaya; 2006.

16. Privindille EA, Marshall RT, Heymann H. Effect of Milkfat, Cocoa, Butter, and Whey Protein Fat Replacers on the Sensory Properties of Lowfat and Nonfat Chocolate Ice Cream. J. Diary Sci. 83:2216-2223; 2000.

17. Avarez, A. V. Ice Cream and Relaten Product. In: Stephani Clark, Michael Costello, MarryAnne Drake, Floyd Bodyfelt (Editor). The Sensory Evaluation of Dairy Product. 2nd Edition. New York: Springer; 2009.p.271-332.

18. J. Sutharut and J. Sudarat. Total Anthocyanin Content and Antioxidant Activity of Germinated Colored Rice. International Food Research Journal 19(1): 215-221; 2012. 